\title{
An Investors' Interest towards Mutual Funds: A Study of Kathmandu Valley, Nepal
}

\author{
Manoj Kumar Chaudhary, Ph.D \\ Associate Professor \\ Central Department of Management \\ Tribhuvan University, Nepal \\ Ajay Prasad Dhakal \\ Associate Professor \\ Center Department of Management, \\ Tribhuvan University, Kathmandu, Nepal \\ Madhav Adhikari, M. Phil Scholar \\ Faculty of Management \\ Tribhuvan University, Nepal
}

\begin{abstract}
The objective of this study is to assess the investor's Mind-set towards mutual funds in Kathmandu valley. To fulfill the stated objectives, a total 230 potential respondents were selected purposively through questionnaire. The collected data are analyzed with the help of descriptive and correlation analysis. In terms of familiarity with the various financial securities currently available in the Nepalese financial market, most of investors familiar with fixed deposits, medium familiarity with shares and very low familiarity with bonds and debentures and money market instruments. The analysis of the results concluded that investors attracted towards mutual fund due to its flexibility, secured type of investment mechanism and Professional management Service in Nepal. Further, it is recommended that concern authority, regulations body, Issue Manager should conduct such training and awareness program showing the importance of mutual funds.
\end{abstract}

Keywords: Investors, attitude, Mutual funds, Financial Securities, Capital Market, Kathmandu.

\section{INTRODUCTION}

Mutual Fund is a type of monetary vehicle that consist a pool of money accumulated from various investors to place assets into protections like stocks, bonds, currency market instruments, and different resources. The Mutual Fund investment should find suitable ways to upgrade purchasers information for settling on more judicious choices (Lashmana Rao,2011).Mutual asset is run by capable financial masters, who administer the resource's assets and attempt to convey capital increments or pay from the diversified investment. A Mutual Fund portfolio is coordinated and kept up to facilitate the venture targets communicated in its arrangement. Mutual Fund is a venture vehicle that pools from customers buying their offers to put resources into an arrangement of protections, with buying and selling securities 
being chosen by a fund manager (Reilly and Brown, 2003). It give little or individual investors admittance to expertly managed arrangement of equities, bonds, and different protections. Every investor, therefore, takes an interest relatively in the gains or losses of the asset. Mutual Funds put resources into an immense number of protections, and execution is normally followed as the adjustment in the complete market cap of the asset is determined by the aggregate execution of the underlying investments. Mutual Funds industry is a developing area due to the elements of investors' insight towards shared asset. Hence they lack the ability to comprehend and to investigate on this matter. In the meantime, investors' discernment and assumption is a lot of significant issue in monetary market (Walia and Kiran, 2009). In this investment apparatuses little investors get advantage from common asset on account of enhancement of venture, proficient administration, affordability and liquidity (Ramamurthy and Reddy, 2005). All in all, the routine method approves attempt to meddle and force limitation on the activities of monetary mediators, with the goal that they can sustain in the monetary market. Due to this reason, mutual funds come up with motivating products and many studies uphold that these limitations help in the advancement of common assets (Ben, Horim, and William L, 1977). The vast majority of women investors by and large evade mutual funds. A principle reason is the absence of awareness, investment methodology; entry and exit move and so on. Desigan et al. (2006)

Rakesh and Shrinivas (2013), with their investigation conducted on 400 financial investors covering the classes of executives and Non-executives on individual investment in Mutual funds saw that 185 investors are keen on putting resources into bank supported shared assets in view of security and 126 financial backers are keen on putting resources into establishments in light of their profits. The remaining 89 investors are keen on putting resources into private area and joint venture to augment their profits and to fence against hazards. This research endeavors to discover the relationship between selected variable and investors' awareness towards mutual funds. An investigation of on age, gender, education, income, and occupation had critical relationship with investors' disposition towards mutual funds; however, they didn't locate any significant relationship directly with mutual funds itself though. (Subramanya and Murthy, 2013). The study in Agra district with 200 respondents found that the segment factors like age, sex, income have solid relationship with the investors' demeanor toward Mutual Fund. Be that as it may, education of the investors had no affected their disposition towards such shared assets (Parihar,2009). In a study on awareness and acceptability of mutual funds led by Singh and Jha, it was found that the purchaser favored mutual fund on account of wellbeing, liquidity and potentiality of return (Singh and Jha, 2009).

The choice of the retail investors is dependent on different dependent variables viz., gender, age, marital status, level of education, level of income, awareness, preference and risk bearing limit (Kannad 2006). Singh 2012 contended that the greater part of the respondents have no legitimate information on the working of shared assets. He found that demographic factors like gender, income and qualification have fundamentally impacted the investors' inclination towards mutual funds. Be that as it may, two demographic factors, to be specific: age and occupation have not been found affecting the disposition of investors' towards common assets. To the extent the advantages given by shared assets are concerned, return potential and liquidity have been seen to be generally appealing to the investors' lured towards it by its adaptability, straightforwardness and reasonableness. 
The effect of the two factors: age and occupation impacts on investors' inclination towards fund reputation and brand name and least starting investment in mutual fund. It is also presumed that occupation is a variable that influences investors' inclinations where as age doesn't assume any part in building the investors' preferences (Shah and Baser 2012). Mutual Fund is a well known idea among the investors, yet it requires more attention to be spread amongst the objective viewers. The components considered by investors by choosing mutual funds for their different speculations and the degree of awareness about SIP, source of information and factors impacting decision making are examined for its determination (Byju 2016). The above awareness factors are contrasted with demographic factors like age, marital status, occupation and gross yearly income of the respondents to break down "the awareness of investment feasibilities in mutual funds.

\section{Research Methodology}

In this study, the primary data has been used to collect information's from respondents through the structured questionnaire. A Total 230 respondent's views were obtained purposively from those who are either engaged or an interested in mutual fund scheme. To test the results, descriptive research design, was used to analyze accordingly. Further, the research has also made some hypothesis and analyzed properly with the help of statistical techniques like Microsoft Excel, and SPSS based on the identified demographic variables. Finally, this research was conducted in Kathmandu Valley.

\section{RESULTS \& Analysis}

In this section, acquired data has been presented in tabular form to know the frequency distributions based on the demographic variables. Further, Data has been analyzed and results are obtained and analyzed it properly. Thus, following demographic frequency distribution table as follows.

Table: 1 Demographic Frequency Distribution

\begin{tabular}{|l|l|l|}
\hline Variables & Factors & No. of. Respondents \\
\hline \multirow{4}{*}{ Age } & Less than 30 years & 48 \\
\cline { 2 - 3 } & $30-45$ years & 145 \\
\cline { 2 - 3 } & $45-60$ years & 31 \\
\cline { 2 - 3 } & 60 above & 6 \\
\hline \multirow{4}{*}{ Gender } & Total & $\mathbf{2 3 0}$ \\
\hline \multirow{5}{*}{ Annual household Income } & Male & 154 \\
\cline { 2 - 3 } & Female & 76 \\
\cline { 2 - 3 } & Total & 230 \\
\hline & Less than 3 lakha & 120 \\
\cline { 2 - 3 } & Between 3 to 5 lakhs & 80 \\
\cline { 2 - 3 } & Above 5 lakhs & 30 \\
\cline { 2 - 3 } & Total & $\mathbf{2 3 0}$ \\
\hline \multirow{2}{*}{ Qualification } & Up to SLC & 25 \\
\cline { 2 - 3 } & Up to Higher Secondary School & 50 \\
\hline
\end{tabular}




\begin{tabular}{|l|l|l|}
\multirow{5}{*}{ Occupation } & Bachalors & $\mathbf{7 7}$ \\
\cline { 2 - 3 } & Masters & 78 \\
\cline { 2 - 3 } & Total & $\mathbf{2 3 0}$ \\
\hline & Business & 60 \\
\cline { 2 - 3 } & Self Employed & 70 \\
\cline { 2 - 3 } & Full time Employee & 95 \\
\cline { 2 - 3 } & Retired & 5 \\
\cline { 2 - 3 } & Total & $\mathbf{2 3 0}$ \\
\hline \multirow{5}{*}{ Saving } & Less than 20\% & 52 \\
\cline { 2 - 3 } & $20-30 \%$ & 140 \\
\cline { 2 - 3 } & $30-50 \%$ & 32 \\
\cline { 2 - 3 } & More than 50\% & 6 \\
\hline & Total & $\mathbf{2 3 0}$ \\
\hline & Married & 170 \\
\hline & Unmarried & 60 \\
\cline { 2 - 3 } & Total & $\mathbf{2 3 0}$ \\
\hline
\end{tabular}

Source: Field Survey,

Table 1 reveals that, 66.95 percent of respondents are male and rest 33.05 percents respondent are females, out of total respondent's majority (63.05\%) are from the age group of 30 to 45 years followed by 13.48 percent respondents are from 45 to 60 years. Only 2.40 percent are above 60 years of age.

Majority of the respondents i.e. 41.30 percent are jobholder and rest 30.47 percent are self employed followed by 26.07 percent who are business. On the basis of education status, 36.87 percent respondents are having qualification of Masters Level and 33.48percent are the Graduated. Out of total 52.17 percent investors in less than 500, 00 Annual household Income holders whereas 34.79 percent and 13.04 percent are 5 lakha to 8 lakha and above 8 lakha respectively. As per the Saving Variables, Majority of the respondents (60.86\%) are able to save between $20 \%$ to $30 \%$ of their total earning followed by 22.60 percent respondent who are able to save less than $20 \%$.

On the Basis of familiarity of Investment Instruments, the respondents were asked about Shares, Debenture, Fixed Deposit, and Government Securities. The scale ranged 4 for most familiar to 1 being unfamiliar in these investment alternatives.

Table 2

Familiarity with various Investment Securities

\begin{tabular}{|c|c|c|c|c|}
\hline \multirow{3}{*}{$\begin{array}{l}\text { Annual Household } \\
\text { Income }\end{array}$} & \multirow[b]{2}{*}{ Familiarity with } & Familiarity & \multirow[b]{2}{*}{ Familiarity with } & \multirow[b]{2}{*}{ Familiarity with } \\
\hline & & & & \\
\hline & \multirow[b]{2}{*}{ Stock (Shares) } & with & \multirow{2}{*}{ Fixed Deposit } & \multirow{2}{*}{$\begin{array}{c}\text { Government } \\
\text { Securities. }\end{array}$} \\
\hline & & Debentures and & & \\
\hline & & Bond & & \\
\hline Less than Rs. 300,000 & 2.70 & 1.60 & 3.38 & 1.50 \\
\hline
\end{tabular}




\begin{tabular}{|c|c|c|c|c|}
\hline $\begin{array}{c}\text { Rs. 3,00,000 to Rs. } \\
5,00,000\end{array}$ & 3.20 & 2.10 & 3.61 & 1.75 \\
\hline Above Rs. 5,00,000 & 3.50 & 2.68 & 3.79 & 2.20 \\
\hline Mean & 3.133 & 2.12 & 3.59 & 1.82 \\
\hline
\end{tabular}

Source: Field Survey,

Table 2 represents the familiarity of the investors towards various investment securities with respect to their Annual Household Income. Firstly, under the savings category of less than Rs. 3, 00,000 the respondents have mean score of 2.70 under the familiarity with shares. This shows that on an average the respondents of this category have medium familiarity with shares. The mean value of familiarity with shares is 3.13 under Table 3 shows that, maximum respondents have more familiar with fixed deposit which represent the overall mean value i.e. 3.59 and less familiar with government securities i.e. 1.82

Table 3

Investment Objective with Respect to Annual Household Income

\begin{tabular}{|c|c|c|c|c|c|}
\hline \multirow{2}{*}{$\begin{array}{c}\text { Annual Household } \\
\text { Income }\end{array}$} & $\begin{array}{c}\text { Capital } \\
\text { Appreciation }\end{array}$ & $\begin{array}{c}\text { Investment Objective } \\
\text { Preservation }\end{array}$ & $\begin{array}{c}\text { Regular } \\
\text { Income } \\
\text { Generation }\end{array}$ & $\begin{array}{c}\text { Portfolio } \\
\text { Management }\end{array}$ & Total \\
\hline $\begin{array}{c}\text { Less than } \\
3,00,000\end{array}$ & 20 & 25 & 30 & 45 & 120 \\
\hline $3,00,000-5,00,000$ & 10 & 5 & 25 & 40 & 80 \\
\hline Above 5,00,000 & 6 & 3 & 6 & 15 & 30 \\
\hline Total & $\mathbf{3 6}$ & $\mathbf{3 3}$ & $\mathbf{6 1}$ & $\mathbf{1 0 0}$ & $\mathbf{2 3 0}$ \\
\hline
\end{tabular}

Source: Field Survey

Table 3 shows that, out of total 230 respondents, 36 respondents have chosen capital appreciation; 33 respondents have chosen capital preservation; 61 respondents have chosen regular income generation and 100 respondents have chosen balanced approach as their investment objective. In this analysis, we have clearly find that the annual household income also effect the investment objective of Investors. In this particular questionnaire, we have asked to investors about investment objective in particular investors who aware in shares, mutual fund also.

While making the decision on Investment, investors depend on various sources for information that can make and influence in their decision-making process. The result of the survey that asked the potential investors of mutual funds regarding the existing source of information that they use to make the investment decision is shown as follows.

Table 04

Investors Decision making process and existing influence factors

\begin{tabular}{|l|l|l|l|}
\hline & Information source use by Investors & & \\
\hline S.N. & Source of Information used & Respondents & Percent. \\
\hline
\end{tabular}




\begin{tabular}{|l|l|l|l|}
1 & Self Analysis & 105 & 45.65 \\
\hline 2 & Friends and Family Advice & 80 & 34.78 \\
\hline 3 & Brokers Advice & 45 & 19.57 \\
\hline & Total & $\mathbf{2 3 0}$ & $\mathbf{1 0 0 \%}$ \\
\hline
\end{tabular}

Source: Field Survey

Table 4 shows the investors decision making process and existing influence factors. Out of Total investors 105 potential investors analysis and decision based on own analysis followed by family and friends advice and broker advice.

Table: 05

Information source Medium while making Investment Decision:

\begin{tabular}{|l|l|l|l|}
\hline & Information Source medium while making & \\
\cline { 4 - 4 } & Investment Decision: & \\
\hline S.N. & Medium & Respondents & Percent \\
\hline & & & \\
\hline & Issue manager and Company Site & 58 & $25.21 \%$ \\
\hline 3 & Online Media and Newspaper & 60 & \\
\hline 4 & Regulator Website & 80 & $26.09 \%$ \\
\hline 5 & TV / News Channel & 20 & $34.80 \%$ \\
\hline & Others & 12 & $8.70 \%$ \\
\hline & Total & $\mathbf{2 3 0}$ & $\mathbf{1 0 0 \%}$ \\
\hline
\end{tabular}

Source: Field Survey

Table 5 represents that the most of the potential investors is for Regulator Website like SEBON and NEPSE followed by Issue manager and company site updates and Online and newspaper for getting the information regarding the value of the Investors source while making investment decision.

Table 06,

Relationship Analysis with Different Variables

\begin{tabular}{|c|c|c|}
\hline Correlation between & $\begin{array}{c}\text { Correlation } \\
\text { Coefficient }\end{array}$ & Result \\
\hline $\begin{array}{c}\text { Different Demographic Variables and Investment } \\
\text { Decision }\end{array}$ & 0.458 & Significant \\
\hline $\begin{array}{c}\text { Mutual Funds Characteristics and Investment } \\
\text { Decision }\end{array}$ & 0.65 & Significant \\
\hline $\begin{array}{c}\text { Influencing Factors and Development of Mutual } \\
\text { fund Schemes }\end{array}$ & 0.156 & significant \\
\hline $\begin{array}{c}\text { Investors Investment Objective and Investment } \\
\text { Decision }\end{array}$ & 0.43 & significant \\
\hline $\begin{array}{c}\text { Return on Investment and Investment in Mutual } \\
\text { funds }\end{array}$ & 0.55 & \\
\hline
\end{tabular}




\begin{tabular}{|c|c|c|} 
Promotional Tools and Investment in Mutual & & \\
Funds & 0.29 & significant \\
\hline Risk Perception and Investment Decisions & 0.583 & Significant \\
\hline
\end{tabular}

Table 6 shows relationship analysis with influencing factors, There is positive relationship between Demographic variables, influencing factors and development of mutual fund schemes, Investors investment objective and investment in mutual funds, return on investment and investment in mutual funds, promotional tools and investment in mutual funds, risk perception of investors and investment decisions and there is significant relationship between characteristics of mutual funds and investment decisions.

\section{Conclusion}

There are many reasons for investors to choose mutual fund investment in the recent days. This professional portfolio manager is being provided with a relatively small price to pay for getting professional help in this sector as well. Mutual funds benefit its investors in terms of flexibility, variety, diversification, liquidity and tax. The major conclusion of the study is that investor's attraction for investment in mutual fund was due to its flexibility and secured type of investment mechanism. Likewise, it was an influencing factor of investment decision amidst their busy schedule, portfolio management service and work schedule. In addition, education level, Marital Status, Awareness Level, also played a vital role besides income and saving of investors amongst other factors. Investment opportunity can be gained due to the access of Mutual funds but they did not know of it beforehand due to inadequate resources and knowledge. Mutual funds provide opportunities to solve the investors' requirements. However, the right way is to do proper selection and have a process for monitoring and controlling the investments. In Nepal, the mutual fund industry is at a growing stage and it is incorporating a higher figure of larger funds every year.

The awareness level of mutual fund among the investors is very low. Having partial knowledge about it prevents them to invest in it as they fear that their funds would go to waste. The Stock Investors Invest in Mutual fund for managing the portfolio and due to opportunity cost and returns base assumption many investors not convincing the it is a growth investment options. In this Paper, we found that, the concept of Nepalese youth about mutual fund is it is the passive investment tools. With proper regulations, policy makers can undertake action to ensure sufficient return on mutual fund investments. Planners should encourage private companies to raise funds capital through such concepts of shared assets. Likewise, the Securities Board of Nepal (SEBON) can arrange education programs on this subject and conduct training program on the importance of mutual funds as well.

\section{REFERENCES}

[1]. Ben, Horim, M., \& William L, S. (1977). Financial Innovations: A Linear Programming Approach. Journal of Banking and Finance (1

[2]. Desigan Gnana, Kalaselvi S and Ansuya L (2006)," Women Consumers Awareness Towards Investment: An empirical Study," Indian Journal of Marketing, Aprilrden E. and Natrajan K. (2010), "Financial Markets and Services' 
[3]. Jani, D., Patel, B., \& Jain, R. (2012). Consumers' Perception towards Mutual Funds as an Investment Option specially focused on Valsad City Located in Gujarat. International Jpurnal ofBusiness Management \& Reseach 2(4), 59-66.

[4]. Kandel, L.R, Investors' Preference towards Mutual Fund: Analytical Evidence From Kathmandu Valley PRAVAHA, 25(1)

[5]. Kannadhasan, M. (2006). Risk appetite and attitudes of retail investors wiht special reference tocapital market.

[6]. Mane, P. (2016). A Study of Investors Perception towards Mutual funds in the city of Aurangabad.

[7]. The SIJ Transactions on Industrial,Financial \& Business Management (IFBM) , 4 (2), 30-38.

[8]. Parihar, B., Sharma, R., \& Parihar, D. (2009). Analyzing Investors' Attitude Towards Mutual funds as an Investment option. The IUP Journal of Management Research 8(7) , 56-64.

[9]. Rakesh, K. \& Srinivas V.S.M. (2013). Understanding individual investors investment behavior in mutual funds : a study on investors of North Coastal Andhra Pradesh. International Journal of Management, 4(3), 185- 198.

[10]. Ramamurthy, B., \& Reddy, S. (2005). Recent Trends in mutual fund industry . SCMS Journal ofIndian Management II(3), 69-76.

[11]. RaoL.k. (2011), Analysis of Consumers awareness towards mutual fund schemes, Zenith International Journal of Multidisciplinary Research, Vol. 1 Issue 8, pp. 175-192

[12]. Reilly, F., \& Brown, K. (2003). Investment Analysis and Portfolio Management (7 ed.). Canada, South Western .

[13]. Shah, A., \& Baser, N. (2012). Mutual Fund : Behavioral Finance Perspective . Asia Pacific Journal ofMarketing \& Management Review .

[14]. Sharma, M., Kaur, H., \& Jain, P. (2012). A study on Factor influencing Satisfaction on Investors Towards Mutual funds Industy using Servqual Model: An Empirical Study. InternationalJournal of Management \& Business Studies 2(4) .

[15]. Sharpe, W. F. (1994). Investment . New Delhi: Prentice Hall of India.

[16]. Shleifer, A. (1999). Inefficeinet Markets: An introduction to behavioral finance . Oxford University Press.

[17]. Singh, B. (2012). A Study on investors' attitude towards mutual funds as an investment otion.

[18]. International Journal of Research in Management 2 (2) .

[19]. Singh, B., \& Jha, A. (2009). An empirical study on awareness and acceptabiltiy of mutual fund.Regional Student's Conference, ICWAL, (pp. 49-55).

[20]. Subramanya, P., \& Murthy, T. (2013). Investors Attitude Towards Mutual funds (Special Reference to Chikkamagalore District, Karnataka State, India). International Journal of Management andBusniess Studies 3(1) Retrieved from http://www.ijmbs.com/31/subra2.phd .

[21]. Treynor, J. (1965). How to rate management of investment fund. Harvard Business Review , 6375.

[22]. Walia, N., \& Kiran, R. (2009). An analysis of investors' risk perception towards mutual funds servicess. International Journal of Business and Management , 4 (5),106. 